\title{
Pengaruh Profitabilitas, Leverage, Dan Firm Size Terhadap Peringkat Obligasi Bank Konvensional Periode 2015-2019
}

Linda Setiawati | Nendi Juhendi | Budi Permana Yusuf

How to cite : Setiawai, L., Juhendi, N., \& Yusuf, B., P.,.(2020). Pengaruh Profitabilitas, Leverage, Dan Firm Size Terhadap Peringkat Obligasi Bank Konvensional Periode 2015-2019. 1(1). Jurnal Jurnal Manajemen Bisnis dan Publik(JMBP). 41-47.

To link to this article : https://doi.org/10.22236/jmbp.v1i1.5686

Opened Access Article

(11) Published Online on 12 November 2020

至 Submit your paper to this journal 
Recieved: 09 Oktober 2020

Accepted: 1 November 2020

Published: 12 November 2020

${ }^{*}$ Corresponding author: Linda Setiawati, Universitas

Muhammadiyah Prof Dr Hamka, Indonesia

E-mail:

lindasetiawati888@gmail.com

Reviewing editor:

Bambang Dwi Hartono, Universitas Muhammadiyah Prof. DR. HAMKA- Jakarta.

Additional information is available at the end of the article

\section{Pengaruh Profitabilitas, Leverage, Dan Firm Size Terhadap Peringkat Obligasi Bank Konvensional Periode 2015-2019}

\author{
Linda Setiawati', Nendi Juhendi, Budi Permana Yusuf
}

\begin{abstract}
Abstrak. Tujuan dari penelitian ini adalah untuk menguji pengaruh dari leverage yang diproksikan dengan Debt Equity Ratio (DER), firm size yang diproksikan dengan (Ln), pengaruh dari DER melalui profitabilitas, pengaruh Ln melalui profitabilitas, pegaruh profitabilitas yang diproksikan dengan Return On Equity (ROE) terhadap peringkat obligasi. Variabel independen yang digunakan dalam pennelitian ini adalah leverage (DER), dan Firm size (Ln). variabel independen dalam penelitian ini adalah peringkat obligasi dan profitabilitas (ROE). Pemilihan sampel ditentukan dengan metode purposive sampling. Sampel yang digunakan dari penelitian ini 10 Bank konvensional yang terdaftar di Bursa Efek Indonesia sejak tahun 2015, melakukan penerbitan obligasi di Bursa Efek Indonesia dan diberikan peringkat oleh PT. PEFINDO dari periode 2015-2019, serta memiliki laba positif secara berturut-turut pada periode penelitian. Tahapan analisis data melalui tiga tahapan yaitu nalisis deskriptif, Uji pemilihan model regresi data panel, uji asumsi klasik, serta pengujian hipotesis melalui analisis jalur, dengan bantuan program Eviews 11. Hasil dari penelitian ini adalah (1) profitabilitas yang diproksikan Return On Equity (ROE) memiliki pengaruh positif dan signifikan terhadap peringkat obligasi dengan nilai koefisien sebesar 0,077 dan sig. 0,0025, (2) leverage yang diproksikan Debt Equity ratio (DER) tidak memiliki pengaruh signifikan terhadap peringkat obligasi dengan koefisien sebesar $-0,009$ dan sig. 0,92, (3) Firm size yang diproksikan (Ln) tidak memiliki pengaruh signifikan terhadap peringkat obligasi dengan koefisien 0,1106 dan sig. 0,16
\end{abstract}

Kata Kunci : Bond Rating, Profitability, Leverage, Firm size

\section{TENTANG PENULIS \\ PENELITIAN SEBELUMNYA}

Linda Setiawati adalah adalah mahasiswa pascasarjana UHAMKA yang lulus pada tahun 2020. la saat ini sedang aktif dalam penelitian-penelitian yang terkait dengan branding suatu produk dalam memasuki pasar nasional dan internasional.

Nendi Juhendi adalah adalah mahasiswa pascasarjana UHAMKA yang lulus pada tahun 2020. la saat ini sedang aktif dalam penelitian-penelitian yang terkait dengan branding suatu produk dalam memasuki pasar nasional dan internasional.

Budi Permana Yusuf adalah Dosen Sekolah Pascasarjana Universitas Muhammadiyah Prof. DR. HAMKA pada program studi Magister Manajemen. la saat ini sedang aktif dalam berbagai penelitian terkait dengan manajemen dan bisnis pada kebijakan publik.

(c) 2020 The Author(s). This open access article is distributed under a Creative Commons Attribution (CC-BY) 4.0 license.
Penelitian sebelumnya membahas kajian manajemen terkait pemasaran produk-produk dengan memperkuat branding. Fokus pada kepemimpinan sumber daya manusia dalam meningkatan produktifitas. Saat ini peneliti membahas Pengaruh Profitabilitas, Leverage, Dan Firm Size Terhadap Peringkat Obligasi Bank Konvensional Periode 2015-2019 


\section{Pendahuluan}

Pasar modal merupakan tempat bertemunya dua pihak, yaitu pihak yang membutuhkan dana (issuer) dan pihak yang memiliki kelebihan dana (investor). Di dalam pasar modal, kedua pihak tersebut dapat melakukan transaksi jual beli instrument keuangan seperti obligasi (surat utang), saham (ekuiti), reksa dana, instrument derivative dan instrumen keuangan lainnya, dengan harapan kedua belah pihak mendapatkan keuntungan. Instrumen yang diperjual belikan di pasar modal dibagi menjadi dua yaitu instrument dengan jangka waktu panjang (lebih dari satu tahun) diantaranya adalah saham, obligasi, waran, right, reksa dana. sedangkan instrument derivative diantaranya adalah option futures, dan lain-lain.

Perkembangan investasi di pasar obligasi kian menarik beberapa tahun belakangan. Hal tersebut ditunjukkan dengan semakin meningkatnya nilai perdagangan obligasi itu sendiri. Berdasarkan data pada IDX Pada tahun 2015 perdagangan untuk obligasi dilihat dari segi volume dan value adalah sebagai berikut : Rp. 90.276 miliar dan Rp. 89.374 miliar. Kemudian mengalami peningkatan pada tahun 2016 menjadi Rp. 126.388 dan Rp. 123.947. Volume dan value penjualan pada tahun 2017 adalah Rp. 325.133 miliar dan Rp. 326.462 miliar, kembali mengalami kenaikan pada tahun 2018 yaitu Rp. 327.617 miliar dan Rp. 327.630 miliar, volume dan value penjualan obligasi terus mengalami kenaikan 2019 menjadi Rp. 388.435 miliar dan Rp.386.118

Obligasi tentu memiliki karakteristik sendiri. Amrullah dalam Veronica (2015) mengemukakan 4 karakteristik obligasi yaitu :

a. Obligasi merupakan surat berharga yang memiliki kekuatan hukum

b. Obligasi memiliki jangka waktu tertentu atau masa jatuh tempo

c. Obligasi memiliki pendapatan secara periodik

d. Terdapat nilai nominal dalam obligasi, nilai nominal tersebut disebut nilai pari, par value, stated value, face value atau nilai kopur.

Sebelum penerbit obligasi (baik korporasi maupun pemerintah) mengeluarkan obligasi, maka akan ada proses pengujian terhadap obligasi tersebut, yang akan dilakukan oleh suatu badan pegawas pasar modal (BAPEPAM) untuk pengujian peringkat obligasi (rating). Adapun proses penerbitan secara keseluruhan memerlukan waktu sekitar 3 hingga 6 bulan, sebelum obligasi tersebut dinyatakan layak terbit dan dapat dibeli investor. Peringkat obligasi diberikan oleh perusahaan pemeringkat yang independen, dan memiliki penilaian yang obyektif, serta terpercaya. Di Indonesia terdapat 6 lembaga pemeringkat obligasi yang diakui oleh Bank Indonesia, salah satunya adalah PT. PEFINDO.

Proses pemeringkatan sebuah obligasi memerlukan waktu kurang lebih hingga dua bulan. Obligasi yang diterbitkan oleh pemerintah otomatis masuk ke dalam golongan investment grade atau berada pada level $A$, hal tersebut karena pemerintah memiliki kemampuan dalam melunasi pokok hutang beserta kuponnya, pada saat jatuh tempo. Berbeda dengan obligasi yang diterbitkan oleh korporasi, biasanya obligasi tersebut memiliki beberapa resiko, salah satunya adalah resiko default (gagal bayar) yang diakibatkan oleh perubahan bisnis. Fabozzi dalam Veronica (2015) mengemukakan 8 kelemahan obligasi sebagai yaitu resiko suku bunga, resiko reinvestasi, resiko gagal bayar, resiko waktu, resiko inflasi, resiko valuta asing, resiko likuidasi dan event risk

Penelitian ini merupakan replikasi dari penelitian Dewi dan Utami (2020) dengan perbedaan sebagai berikut:

a. Menambah variabel independen yaitu leverage, yang mengacu pada penelitian Saputri dan Purbawangsa (2016) dan ukuran perusahaan yang mengacu pada penelitian Sari dan Badjra (2016). Penambahan variabel leverage dilakukan karena variabel leverage dalam hal ini DER merupakan salah satu rasio keuangan yang berpengaruh positif, peningkatan utang membawa manfaat berupa penambahan modal untuk mengembangkan 
perusahaan. Sedangkan penambahan variabel firm size dilakukan karena investor memiliki tingkat kepercayaan yang tinggi terhadap perusahaan besar, hal ini menyebabkan semakin tinggi peringkat yang diberikan oleh badan pemeringkat.

b. Menguji variabel profitabilitas menjadi variabel mediasi pada pengaruh Firm size terhadap peringkat obligasi dan leverage terhadap peringkat obligasi

c. Variabel independen likuiditas tidak diuji lagi pada penelitian ini, karena pada penelitian sebelumnya likuiditas yang diproksikan CR (current ratio) tidak berpengaruh signifikan terhadap peringkat obligasi.

d. Objek penelitian yang digunakan pada penelitian sebelumnya adalah perusahaan non keuangan yang terdaftar di BEI secara berturut-turut pada periode 2014-2018 dan di peringkat oleh PT. PEFINDO, sedangkan objek penelitian yang digunakan pada penelitian ini adalah perusahaan yang bergerak di bidang perbankan konvensional yang terdaftar di Bursa Efek Indonesia secara berturut-turut pada periode 2015-2019.

\section{Kajian Teori}

\subsection{Signalling Theory}

Signalling theory pertama kali diperkenalkan oleh Spence pada tahun 1973. Teori ini menekankan kepada pentingnya informasi yang dikeluarkan oleh perusahaan terhadap keputusan investasi pihak di luar perusahaan. Brigham dan Houston (2011) mengartikan Signalling theory sebagai suatu tindakan yang diambil oleh manajemen suatu perusahaan untuk memberikan petunjuk investor tentang bagaimana manajamen menilai prospek perusahaan. Sinyal tersebut diharapkan agar pasar maupun pihak eksternal melakukan perubahan penilaian atas suatu perusahaan. Puput (2011) menyatakan bahwa terdapat kandungan informasi pada pengungkapan suatu informasi yang dapat menjadi sinyal bagi investor dan pihak potensial lainnya dalam mengambil keputusan ekonomi. Sedangkan menurut Mirah, Devi dan Suardika (2014) dalam Pertiwi (2018) Informasi tersebut penting bagi investor karena pada hakikatnya, penyajian keterangan berupa catatan atau gambaran tentang keadaan masa lalu, saat ini, maupun masa yang akan datang bagi kelangsungan hidup da bagaimana efeknya pada perusahaan. Handyansyah dan Lestari (2016) adapun sinyal yang diberikan perusahaan melalui laporan keuangan meliputi analisis-analisis rasio keuangannya, seperti ROA, ROE, NPM, dan EPS guna mempengaruhi keputusan para investor dalam berinvestasi.

Sinyal positif maupun negatif akan mempengaruhi kondisi pasar, sehingga, sebisa mungkin perusahaan mempunyai dorongan untuk memberikan informasi laporan keuangan pada pihak eksternal. Sinyal tersebut dapat berupa promosi maupun informasi yang menyatakan bahwa perusahaan tersebut lebih unggul daripada perusahaan lain. Informasi - informasi tersebut pada dasarnya menyajikan keterangan atau menggambarkan keadaan beberapa tahun sebelumnya, saat ini, maupun masa yang akan datang bagi kelangsungan hidup suatu perusahaan.

\subsection{Obligasi}

Obligasi merupakan surat utang jangka menengah yang dapat dipindah tangankan, yang berisi janji dari pihak yang menerbitkan untuk membayar imbalan berupa bunga pada periode tertentu dan melunasi pokok utang pada waktu yang telah ditentukan kepada pihak pembeli obligasi tersebut (https://www.idx.co.id). Menurut Kasmir (2005) dalam Leli (2017) obligasi merupakan instrument hutang bagi perusahaan yang hendak memperoleh modal, keuntungan dari 
membeli obligasi diwujudkan dalam bentuk kupon. Tujuan penerbitan obligasi adalah untuk mendapatkan dana segar dari investor, yang mana penerbit juga harus membayarkan imbal hasil berupa kupon setiap bulannya, sesuai dengan yang telah disepakati kedua belah pihak.

\subsection{Peringkat Obligasi}

Peringkat Obligasi merupakan skala rasio dari sebuah perusahaan. Kidwell dkk. (2016) mendefinisikan peringkat obligasi sebagai resiko default perusahaan menurut lembaga pemeringkat. Menurut PEFINDO (2017) peringkat obligasi adalah sebuah kajian menyeluruh atas kelayakan kredit sebuah perusahaan, atau kemampuannya untuk memenuhi seluruh kewajiban keuangannya, kajian tersebut merujuk pada penilaian tiga resiko utama perusahaan yaitu resiko industri, resiko bisnis, dan resiko keuangan.

Peringkat ini secara umum dipengaruhi oleh proporsi modal terhadap hutang perusahaan, tingkat profitabilitas perusahaan, tingkat kepastian dalam menghasilkan pendapatan, besar kecilnya perusahaan dan sedikit penggunaan hutang subordinat. Berdasarkan keputusan BAPEPAM dan Lembaga Keuangan Kep-151/BL/2009, peringkat obligasi adalah opini dari lembaga pemeringkat serta sumber informatif bagi pemodal atas resiko obligasi yang diperdagangkan. Informasi peringkat tersebut diharapkan menjadi bahan pertimbangan bagi pemilik modal untuk mengambil keputusan dalam berinvestasi.

Informasi yang dikeluarkan oleh badan pemeringkat akan memudahkan investor dalam memilih sekuritas obligasi yang tepat. Peringkat obligasi ini memberikan signal tentang probabilitas kegagalan hutang suatu perusahaan Fauziah (2014). Berikut adalah peringkat Obligasi yang digunakan oleh PT PEFINDO:

Tabel 1. Peringkat Obligasi

\begin{tabular}{llll}
\hline 1. & idAAA & 10. & idBBB- \\
\hline 2. & idAA+ & 11. & idBB+ \\
\hline 3. & idAA & 12. & idBB \\
\hline 4. & idAA- & 13. & idBB- \\
\hline 5. & idA + & 14. & idB+ \\
\hline 6. & idA & 15. & idB \\
\hline 7. & idA- & 16. & idB- \\
\hline 8. & idBBB+ & 17. & idC \\
\hline 9. & idBBB & 18. & idD \\
\hline
\end{tabular}

Sumber : Pefindo

Rahardjo (2004) mengemukakan beberapa manfaat peringkat obligasi, bagi investor sebagai berikut :

a. Informasi resiko Investasi

Tujuan utama investasi adalah untuk mendapatkan keuntungan dan meminimalkan resiko. Oleh karena itu, dengan adanya peringkat obligasi, diharapkan informasi resiko dapat diketahui lebih jelas posisinya.

b. Rekomendasi Investasi

Mempermudah investor dalam mengambil keputusan investasi berdasarkan hasil peringkat kinerja emiten obligasi tersebut. dengan demikian, investor dapat melakukan strategi investasi baik membeli maupun menjual sesuai dengan perencanaannya.

c. Perbandingan 
Hasil pemeringkatan obligasi akan dijadikan patokan dalam membandingkan obligasi yang satu dengan yang lainnya, serta menjadi pembanding stuktur lainnya seperti suku bunga dan metode penjaminnya.

Adapun manfaat yang didapatkan oleh emiten diantaranya adalah :

a. Informasi Posisi Bisnis

Perusahaan dapat mengetahui bisnis dan kinerja usahanya dibandingkan dengan perusahaan sejenisnya.

b. Menentukan Struktur Obligasi

Perusahaan dapat menentukan beberapa syarat atau stuktur obligasi yang meliputi tingkat suku bunga, jenis obligasi, jangka waktu jatuh tempo, jumlah emisi obligasi, serta stuktur pendukung lainnya.

c. Mendukung Kinerja

Jika emiten mendapat peningkatan cukup bagus, maka kewajiban menyediakan sinking fund atau jaminan kredit bisa dijadikan pilihan alternatif.

d. Alat Pemasaran

Peringkat obligasi yang baik terlihat lebih menarik, sehingga dapat membantu pemasaran obligasi.

e. Menjaga kepercayaan Investor

Peringkat obligasi yang independen akan membuat investor merasa lebih aman.

\subsection{Profitabilitas}

Menurut Wegyandt dkk (2015) rasio profitabilitas mengukur pendapatan atau keberhasilan operasi suatu perusahaan dalam jangka waktu tertentu. Novtaviani dan Oetomo (2019) rasio ini memberikan ukuran mengenai tingkat efektivitas manajemen atau perusahaan, yang ditunjukkan oleh laba yang dihasilkan dari penjualan dan investasi dan menunjukkan kinerja sebuah perusahaan baik jika profitabilitasnya tinggi. Terdapat 3 rasio yang digunakan dalam dalam rasio profitabilitas, diantaranya adalah : Return On Asset, Return On Equity dan Net Profit Margin.

Skala pengukuran pada penelitian ini menggunakan skala rasio Return On Equity. ROE adalah rasio yang menunjukkan seberapa besar perusahaan dapat menghasilkan return (keuntungan) dari hasil pengelolaan modal yang dimiliki perusahaan tersebut, baik modal sendiri maupun modal yang berasal dari investor. Menurut Hery (2015) ROE merupakan rasio yang menunjukkan seberapa besar konstribusi modal dalam menciptakan laba bersih. Rasio ini mencerminkan penerimaan perusahaan atas peluang investasi yang baik dan manajemen yang efektif. Jika ROE yang dimiliki sebuah perusahaan tinggi, maka perusahaan tersebut telah efektif dalam megelola modalnya, sehingga akan mengundang kepercayaan para investor untuk berinvestasi di perusahaan tersebut.

\subsection{Leverage}

Leverage merupakan tingkat hutang yang digunakan perusahaan dalam melakukan pembiayaan. Menurut Kasmir (2017) Leverage adalah rasio untuk mengukur seberapa besar aktivitas perusahaan dibiayai oleh hutang. Sebuah perusahaan yang memiliki leverage yang tinggi, mengindikasikan bahwa perusahaan tersebut cenderung memiliki kemampuan yang rendah dalam memenuhi kewajibannya. Kegiatan perusahaan yang dibiayai oleh hutang yang terlalu besar, maka 
semakin besar pula kemungkinan terjadinya financial distress akibat tingginya kewajiban perusahaan membayar hutang Putri dan Mulyani (2019).

Pada penelitian ini, leverage diproksikan Debt Equity Ratio (DER). DER adalah rasio yang membandingkan seberapa besar hutang perusahaan dibandingkan dengan ekuitas. Rasio ini juga menggambarkan sejauh mana modal yang dimiliki sebuah perusahaan untuk menutupi hutanghutangnya dari pihak luar.

\subsection{Firm Size}

Besar kecilnya perusahaan dapat diklasifikasikan antara lain dengan menganalisis : total aktiva, nilai pasar, saham, dan lain-lain. Brigham \& Houston dalam Sari dan Badjra (2016) mendefinisikan ukuran perusahaan sebagai rata-rata total penjualan bersih untuk tahun yang bersangkutan sampai beberapa tahun, ukuran perusahaan juga merupakan karakteristik suatu perusahaan dalam hubungannya dengan stuktur perusahaan. Kriteria ukuran perusahaan diatur dalam UU No. 20 tahun 2008 adalah sebagai berikut:

Tabel 2 Kriteria Ukuran Perusahaan

\begin{tabular}{lcc}
\hline \multirow{2}{*}{ Ukuran Perusahaan } & \multicolumn{2}{c}{ Kriteria } \\
\cline { 2 - 3 } & $\begin{array}{c}\text { Assets (Tidak termasuk tanah } \\
\text { dan bangunan tempat usaha) }\end{array}$ & Penjualan Tahunan \\
\hline Usaha Mikro & Maksimal 50 juta & Maksimal 300 juta \\
\hline Usaha Kecil & $>50$ juta -500 juta & $>300$ juta $-2,5 \mathrm{M}$ \\
\hline Usaha Menengah & $>500$ juta $-10 \mathrm{M}$ & $>2,5 \mathrm{M}-50 \mathrm{M}$ \\
\hline Usaha Besar & $>10 \mathrm{M}$ & $>50 \mathrm{M}$ \\
\hline Sumber : UU No. 20 tahun 2008 & &
\end{tabular}

Machfoedz dalam Ibrahim (2018) membagi ukuran perusahaan kedalam tiga, yaitu large firm (perusahaan besar), medium size (perusahaan menengah) dan small firm (perusahaan kecil). Penentuan ukuran perusahaan ini berdasarkan pada total asset perusahaan. Sedangkan Hartono (2015) menjelaskan ukuran perusahaan adalah besar kecilnya perusahaan dapat diukur dengan total aktiva atau besar harta perusahaan dengan menggunakan perhitungan nilai logaritma total aktiva. Aktiva merupakan salah satu indikator terpenting dalam menentukan skala perusahaan. Perusahaan yang besar, biasanya memiliki nilai aktiva yang besar pula, karena perusahaan besar tentu sudah memiliki prospek ke depan yang lebih jelas, dibandingkan dengan perusahaan yang kecil. Adapun indikator untuk mengukur Total Asset menurut Hartono (2015), yaitu Ukuran Perusahaan $=$ Ln Total Assets.

\subsection{Pengembangan Hipotesis}

\subsubsection{Pengaruh Langsung DER Terhadap Peringkat Obligasi}

Sakinah, Paminto dan Kadafi (2017) DER secara statistik berpengaruh positif signifikan terhadap peringkat obligasi, jika perusahaan dapat mengelola dana yang dipinjamnya dengan baik maka akan mampu menghasilkan profit (digunakan untuk ekspansi, investasi maupun menambah produk baru). 
$\mathrm{H}_{1}$ : Terdapat pengaruh langsung positif dan signifikan antara leverage (DER) terhadap peringkat obligasi.

\subsubsection{Pengaruh Langsung Firm Size Terhadap Peringkat Obligasi}

Berdasarkan penelitian terdahulu yang dilakukan Veronica (2015) menunjukkan ukuran perusahaan mempunyai pengaruh yang signifikan terhadap peringkat oligasi, hasil penelitian menunjukkan bahwa semakin besar perusahaan, maka semaikin tinggi peringkat obligasi yang diberikan yang disebabkan oleh tingginya tingkat kepercayaan dari investor.

$\mathrm{H}_{2}$ : Terdapat pengaruh langsung positif dan signifikan antara Firmsize (Ln) terhadap peringkat obligasi

\subsubsection{Pengaruh Tidak Langsung DER Terhadap Peringkat Obligasi Melalui Profitabilitas}

Dengan menggunakan kerangka berfikir di atas, terdapat pengaruh langsung DER terhadap peringkat obligasi, maka dapat disimpulkan juga bahwa terdapat pengaruh tidak langsung DER terhadap peringkat obligasi melalui profitabilitas.

$\mathrm{H}_{3}$ : Terdapat pengaruh tidak langsung antara leverage (DER) terhadap peringkat obligasi melalui profitabilitas

\subsubsection{Pengaruh Tidak Langsung Ln Terhadap Peringkat Obligasi Melalui Profitabilitas}

Dengan menggunakan kerangka berfikir di atas, terdapat pengaruh langsung Ln terhadap peringkat obligasi, maka dapat disimpulkan juga bahwa terdapat pengaruh tidak langsung Ln terhadap peringkat obligasi melalui profitabilitas.

$\mathrm{H}_{4}$ : Terdapat pengaruh tidak langsung antara Firmsize $(\mathrm{Ln})$ terhadap peringkat obligasi melalui profitabilitas

\subsubsection{Pengaruh Langsung ROE Terhadap Peringkat Obligasi}

Dewi dan Utami (2020) yang menunjukkan pengaruh positif signifikan ROE terhadap peringkat obligasi, semakin tinggi ROE, maka semakin tinggi peringkat obligasinya, begitupun sebaliknya.

$\mathrm{H}_{5}$ :Terdapat pengaruh langsung positif dan signifikan antara Profitabilitas (ROE) terhadap peringkat obligasi

\section{Metode Penelitian}

\subsection{Populasi dan Sampel Penelitian}

Populasi dalam penelitian ini adalah seluruh bank konvensional yang terdaftar di Bursa Efek Indonesia pada tahun 2015-2019. Teknik pengambilan sampel yang digunakan adalah purposive Jurnal Manajemen Bisnis dan Publik 
sampling. Kriteria yang digunakan adalah sebagai berikut: (1) seluruh sektor perbankan konvensional yang terdaftar di Indonesia sejak tahun 2015, (2) perusahaan sektor perbankan yang menerbitkan obligasi di Bursa fek Indonesia, serta diberikan peringkat oleh PT. PEFINDO secara berturut-turut pada tahun 2015-2019, (3) perusahaan yang secara periodik melaporkan laporan keuangannya tahun 2015-2019, (4) perusahaan sektor perbankan yang memiliki laba positif secara berturut-turut pada periode 2015-2019.

\subsection{Definisi Operasional dan Pengukuran Variabel}

\subsubsection{Variabel Dependen}

Peringkat Obligasi

Variabel dependen dalam penelitian ini adalah peringkat obligasi. Skala pengukuran yang digunakan adalah skala ordinal, karena merupakan variabel dummy.

Investment grade $=A A A, A A+A A, A, A-, B B B+, B B B$

Non Investment grade $=\mathrm{BBB}-, \mathrm{BB}+, \mathrm{BB}, \mathrm{BB}-, \mathrm{B}+, \mathrm{B}, \mathrm{B}-, \mathrm{C}, \mathrm{D}$

\subsubsection{Variabel Independen}

a. Leverage (DER)

Skala pengukuran DER menggunakan skala rasio. Berikut adalah rumus yang digunakan untuk menghitung DER menurut Harahap (2010):

DER = Total Hutang $/$ Modal Sendiri

b. Firm Size (Ln)

Skala pengukuran Firm size menggunakan skala rasio. Adapun indikator untuk mengukur Total Asset menurut Hartono (2015), yaitu :

$$
\operatorname{Ln}=\operatorname{Ln}(\text { Total asset })
$$

\subsubsection{Variabel Mediasi}

Profitabilitas (ROE)

Variabel mediasi pada penelitian ini adalah profitabilitas, yang mana menggunakan skala rasio dalam pengukurannya. Menurut Sartono (2012 : 123) ROE dapat hitung dengan cara

$$
\mathrm{ROE}=\text { laba bersih setelah pajak / ekuitas pemegang saham }
$$

\subsection{Uji Hipotesis}

Pada penelitian ini penulis menggunakan jenis data kuantitatif yakni jenis data yang diperoleh dalam bentuk angka-angka yang dapat dihitung, yang diperoleh dari laporan keuangan 
Bank Konvensional yang terdaftar di Bursa Efek Indonesia, serta diberikan peringkat oleh PT. PEFINDO periode tahun 2015-2019.

Analisis jalur merupakan uji yang digunakan untuk menganalisis pola hubungan diantara variabel. Menurut Ghozali (2013 : 249) analisis jalur digunakan untuk menentukan pola hubungan antara tiga atau lebih variabel dan tidak dapat digunakan untuk mengkonfirmasi atau menolak hipotesis kasualitas imajiner. Dalam penelitian ini hubungan antar variabel bebas (profitabilitas, leverage, dan firm size) dengan variabel terikat (peringkat obligasi) dapat digambarkan dengan model persamaan Path Analysis sebagai berikut:

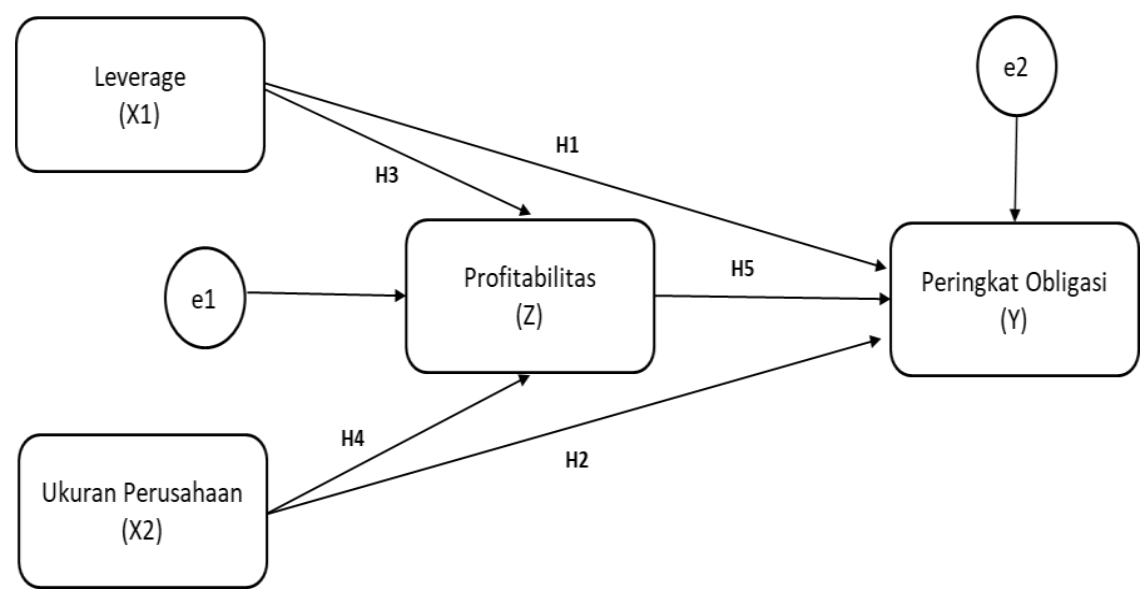

Gambar 1 Model Diagram Analisis Jalur

Diagram jalur di atas terdiri dari dua persamaan, di mana leverage dan firm-size adalah variabel eksogen, sedangkan profitabilitas dan peringkat obligasi adalah variabel endogen. Berikut persamaan yang digunakan dalam diagram jalur di atas:

$$
\begin{gathered}
Z=\alpha_{1}+\beta_{1} X_{1}+\beta_{2} X_{2}+\varepsilon_{1} \\
Y=\alpha_{2}+\beta_{3} X_{1}+\beta_{4} X_{2}+\beta_{5} Z+\varepsilon_{1}
\end{gathered}
$$

di mana :

$$
\begin{array}{ll}
Z & =\text { Profitabilitas } \\
Y & =\text { Peringkat Obligasi } \\
A & =\text { Kostanta } \\
\beta_{1}-\beta_{5} & =\text { Koefisien Regresi }
\end{array}
$$

$$
\begin{array}{ll}
\mathrm{X}_{1} & =\text { Leverage } \\
\mathrm{X}_{2} & =\text { Ukuran Perusahaan } \\
\mathrm{e} & =\text { Error }
\end{array}
$$

\section{HASIL DAN PEMBAHASAN}

\subsection{Statistik Deskriptif}

Tabel 3 menunjukkan statistik deskriptif masing-masing variabel penelitian, yaitu profitabilitas, leverage, firm size dan Peringkat Obligasi. Adapun penjelasanya adalah sebagai berikut :

Tabel 3 Statistik Deskriptif

ROE DER Ln $\begin{gathered}\begin{array}{c}\text { Peringkat } \\ \text { Obligasi }\end{array} \\ \text { On }\end{gathered}$




\begin{tabular}{lllll}
\hline Mean & 10.05520 & 7.500200 & 32.56940 & 14.90000 \\
\hline Medium & 9.880000 & 6.550000 & 32.79500 & 17.00000 \\
\hline Maximum & 22.46000 & 14.75000 & 34.89000 & 17.00000 \\
\hline Minimu & 1.000000 & 3.260000 & 25.19000 & 10.00000 \\
\hline Std. Dev & 4.795505 & 2.644697 & 1.929876 & 2.858928 \\
\hline
\end{tabular}

Sumber : data sekunder diolah enggunakan Eviews 11 tahun 2020

ROE digunakan untuk mengetahui kekuatan bank dalam mengatur modal agar dapat menghasilkan keuntungan setelah pajak. Berdasarkan data pada tabel 4.2 nilai minimum ROE adalah sebesar 1,00\% yaitu Tabungan Negara Tbk pada tahun 2019 dan nilai maksimum sebesar 22,46\% PT. Bank BRI pada tahun 2015. Mean, median, dan standard deviation ROE masingmasing sebesar $10,06 \%, 9,88 \%$ dan $4,80 \%$

DER digunakan untuk mengetahui kemampuan perusahaan dalam membayar hutang baik jangka panjang maupun jangka pendek. Pada tabel 4.2 nilai minimum DER adalah $3.26 \%$ yaitu Bank Danamon pada tahun 2019 dan nilai maksimum sebesar 14.75 yaitu Bank Bukopin pada tahun 2017. Mean, median, dan standard deviation ROE masing-masing sebesar 7,50\%, 6,55\% dan $2,64 \%$.

Variabel Firm size digunakan untuk mengetahui seberapa besar sebuah perusahaan. Variabel ini diproksikan dengan Ln. pada tabel 4.2 nilai minimum Ln adalah $25,19 \%$ yaitu Bank Mayapada pada tahun 2018, dan nilai maksimum yaitu 34,89\% yaitu Bank BRI pada tahun 2019. Mean, median, dan standard deviation ROE masing-masing sebesar 32,57\%, 32,80\% dan 1,93\%.

\subsection{Uji Pemilihan Model}

Untuk menentukan model regresi data panel yang paling tepat, dapat dilakukan dengan menggunakan uji chow, uji hausman, dan uji LM. ketiga uji tersebut dilakukan dengan melihat nilai probabilitas cross section chi-square untuk uji chow dan hausman, sedangkan uji LM dilakukan dengan melihat nilai probabilitas Breusch-Pagan.

Tabel 4 Pemilihan Model Regresi Data Panel Model Substuktur 1

\begin{tabular}{|c|c|c|c|c|c|c|c|c|}
\hline Variabel & Model & & & Uji I & sman & & & Model \\
\hline Profitabilitas & 1 & $\begin{array}{l}0.0039 \\
<0.05\end{array}$ & Fixed & $\begin{array}{l}0.8686 \\
>0.05\end{array}$ & Random & $\begin{array}{l}0.0248 \\
<0.05\end{array}$ & Random & Random \\
\hline $\begin{array}{l}\text { Peringkat } \\
\text { Obligasi }\end{array}$ & 2 & $\begin{array}{l}0.0000 \\
<0.05\end{array}$ & Fixed & $\begin{array}{l}0.0030 \\
<0.05\end{array}$ & Fixed & & & Fixed \\
\hline
\end{tabular}

Sumber : Data Olahan Eviews 11 tahun 2020

Berdasarkan tabel di atas, pada uji chow probabilitas menunjukkan angka 0,0039 yaitu lebih kecil dari 0,05 maka $\mathrm{H}_{0}$ ditolak dan $\mathrm{H}_{1}$ diterima, yang berarti bisa ditarik kesimpulan sementara bahwa fixed effect model adalah model yang tepat digunakan dalam model ini. kemudian setelah itu, dilakukan uji hausman, probabilitas menunjukkan angka 0,8686 yaitu angka lebih besar dari 0,05 maka $\mathrm{H}_{0}$ diterima dan $\mathrm{H}_{1}$ ditolak. Kemudian, yang terakhir uji Lagrange Multiplier di mana hasilnya menunjukkan probabilitas sebesar 0.0248 yang berarti lebih kecil dari 0.05 maka $\mathrm{H}_{0}$ ditolak dan $\mathrm{H}_{1}$ diterima. Berarti model yang tepat digunakan dalam substuktur model 1 adalah random effect model.

Pada model 2 uji chow probabilias menunjukkan angka 0.0000 yaitu lebih kecil dari 0.05 maka $\mathrm{H}_{0}$ ditolak dan $\mathrm{H}_{1}$ diterima yang berarti dapat ditarik kesimpulan sementara bahwa fixed 
model adalah model yang tepat digunakan dalam model ini. Kemudian setelah itu dilakukan uji hausman, probabilitas menunjukkan angka 0.0030 yaitu lebih kecil dari 0.05 maka $\mathrm{H}_{0}$ ditolak dan $\mathrm{H}_{1}$ diterima, berarti model yang tepat digunakan sebagai model substuktur model 2 adalah fixed effect model.

\subsection{Pengujian Hipotesis}

Analisis jalur yang biasa disebut path analysis merupakan teknik analisis yang digunakan untuk mempelajari hubungan kausal antara variabel bebas dengan variabel terikat. Dalam penelitian ini hubungan antara variabel bebas (leverage dan firmsize) dengan variabel terikat (peringkat obligasi) dan variabel mediasi (profitabilitas) dijelaskan pada tabel berikut :

Tabel 5 Ringkasan Koefisien Jalur

\begin{tabular}{lccccc}
\hline \multicolumn{1}{c}{ Variabel } & Coeff beta & St. Error & t-hitung & Prob. & Keterangan \\
\hline DER $>$ PO & -0.009370 & 0.093335 & -0.100390 & 0.9206 & Tidak Signifikan \\
\hline Ln $>$ PO & 0.110611 & 0.078273 & 1.413134 & 0.1660 & Tidak Signifikan \\
\hline ROE $>$ PO & 0.076768 & 0.023675 & 3.242628 & 0.0025 & Signifikan \\
\hline DER $>$ ROE & -0.420823 & 0.329083 & -1.278775 & 0.2073 & Tidak signifikan \\
\hline Ln $>$ ROE & 0.939573 & 0.389055 & 2.415014 & 0.0197 & Signifikan \\
\hline
\end{tabular}

Sumber : data Olahan Eviews 11, 2020

Besarnya e yang merupakan pengaruh variabel lain terhadap ROE dapat dapat dihitung dengan $e=\sqrt{(1-0,16)}=0,916$. Besarnya $e 2$ yang merupakan pengaruh variabel lain terhadap peringkat obligasi dihitung dengan $e 2=\sqrt{(1-0,97)}=0,17$. Berdasarkan tabel ringkasan koefisien jalur dan perhitungan e di atas, maka didapatkan persamaan stuktural sebagai berikut:

a. $\mathrm{ROE}=-0.42 \mathrm{DER}+0.94 \mathrm{Ln}+0.916$

b. $P O=0,009 \mathrm{DER}+0.11 \mathrm{Ln}+0.077 \mathrm{ROE}+0.17$

Berikut adalah diagram jalur dari persamaan stuktural di atas:

Peringkat Obligasi $=0,077$ ROE $+0,009$ DER $+0,1106 \mathrm{Ln}+0,17$

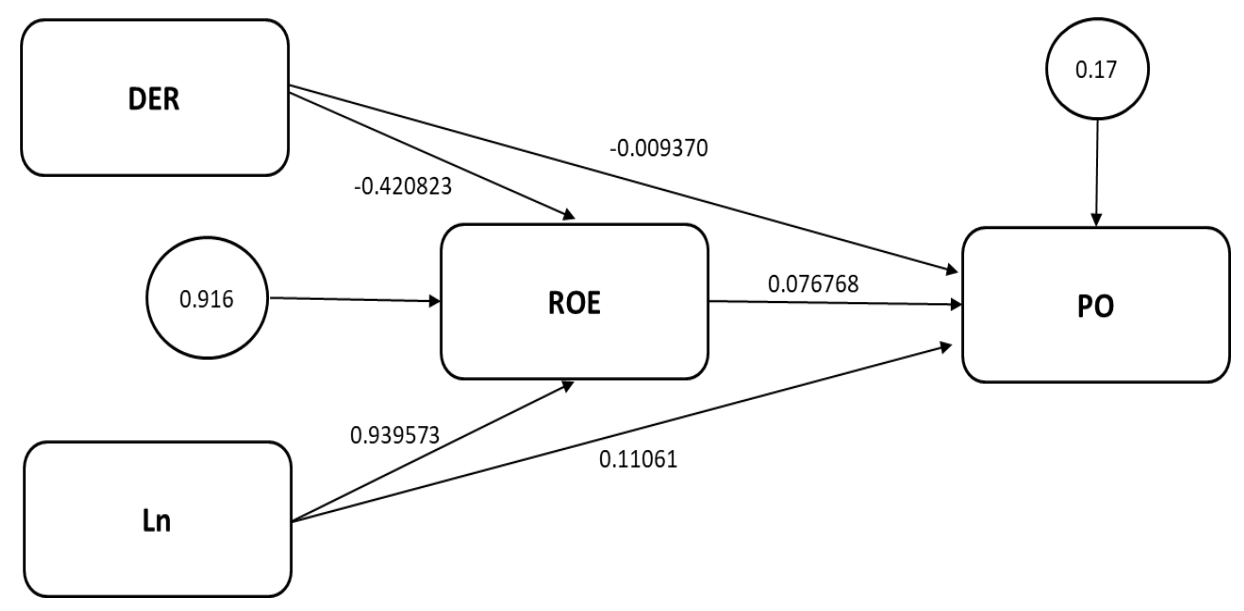

Gambar 2 Diagram Jalur Sumber , Eviews (2020) 
Berdasarkan pengujian atau pengolahan data melalui Eviews 11, maka diperoleh hasil uji hipotesis sebagai berikut:

a. Pengaruh langsung positif dan signifikan antara leverage (DER) terhadap peringat obligasi

Variabel leverage mempunyai koefisien beta sebesar -0.009 . hasil ini berarti leverage memiliki pengaruh negatif pada peringkat obligasi. Nilai profitabilitas variabel leverage dalam penelitian ini adalah sebesar 0.92 . nilai tersebut lebih besar dari tingkat signifikansi $(a)=5 \%$ atau 0.05 , yang berarti leverage tidak berpengaruh signifikan pada peringkat obligasi. Hasil analisis ini menunjukkan bahwa $\mathrm{H}_{0}$ diterima dan $\mathrm{H}_{a}$ ditolak. Oleh karena itu, disimpulkan bahwa leverage tidak memiliki pengaruh langsung terhadap peringkat obligasi.

Hasil penelitian ini mendukung penelitian yang dilakukan oleh Sari dan Badjra (2016), Pethy (2018) dan Hidayat (2018) yang membuktikan bahwa DER tidak memiliki pengaruh langsung signifikan terhadap peringkat obligasi.

b. Pengaruh langsung positif dan signifikan antara Firmsize (Ln) terhadap peringat obligasi

Variabel firm size mempunyai koefisien beta sebesar 0.1106 . hasil ini berarti ukuran prusahaan memiliki pengaruh positif pada peringkat obligasi. Nilai probabilitas variabel firm size dalam penelitian ini adalah sebesar 0.16 . nilai tersebut lebih besar dari tingkat signifikansi (a) $=5 \%$ atau 0.05 , yang berarti firm size tidak berpengaruh signifikan pada peringkat obligasi. Hasil analisis ii menunjukkan bahwa $\mathrm{H}_{0}$ diterima dan $\mathrm{H}_{a}$ ditolak. Oleh karena itu, dapat disimpulkan bahwa firm size tidak memiliki pengaruh langsung terhadap peringkat obligasi.

Hasil penelitian ini mendukung penelitian yang dilakukan oleh Kurniasih (2015) dan Wijayanti (2015) yang membuktikan bahwa Ln tidak berpengaruh terhadap peringkat obligasi. Hal ini sebab untuk melihat perigkat obligasi dalam pengukuran size, sebaiknya dilihat dari segi kewajiban perusahaan, bukan dari total asetnya.

c. Pengaruh tidak langsung langsung positif dan signifikan leverage (DER) terhadap peringat obligasi melalui profitabilitas

Besarnya pengaruh tidak langsung leverage terhadap peringkat obligasi melalui profitabilitas dapat dihitung dengan cara mengkalikan koefisien beta yaitu $(0.420823 \mathrm{x}$ $0.076768)=-0.003230574$. total pengaruh leverage terhadap peringkat obligasi adalah sebesar $-0.009370+-0.003230574=-0.096930574$. hasil perhitungan dengan uji sobel menunjukkan nilai standar error pengaruh tidak langsung sebesar 0.025 dan menunjukkan $t$ hitung sebesar 1.2936 lebih kecil dari t tabel dengan tingkat signifikansi 0.055 yaitu 1.684 . Hasil uji mediasi ini menunjukkan bahwa $\mathrm{H}_{0}$ diterima dan $\mathrm{H}_{a}$ ditolak. Oleh sebab itu dapat disimpulkan bahwa tidak terdapat pengaruh tidak langsung leverage terhadap peringkat obligasi melalui profitabilitas

d. Pengaruh tidak langsung langsung positif dan signifikan Firmsize (Ln) terhadap peringat obligasi melalui profitabilitas 
Besarnya pengaruh tidak langsung firm size terhadap peringkat obligasi melalui profitabilitas $(\mathrm{ROE})$ dihitung dengan cara mengalikan koefisien beta yaitu $(0.939573 \times 0.076768)=$ $0.110611+0.0721291401=0.1827401401$. hasil perhitungan dengan uji sobel menunjukkan nilai standar error pengaruh tidak langsung sebesar 0.036 dan menunjukkan nilai t hitung sebesar 2.0105 lebih kecil dari t tabel dengan tingkat signifikansi 0.05 yaitu 1.684 . hasil analisis uji mediasi ini menunjukkan bahwa $\mathrm{h}_{0}$ ditolak dan $\mathrm{H}_{a}$ diterima. Oleh karena itu, dapat disimpulkan bahwa terdapat pengaruh tidak langsung firm size terhadap peringkat obligasi melalui profitabilitas.

\section{e. Pengaruh langsung positif dan signifikan antara Profitabilitas (ROE) terhadap peringat obligasi}

Variabel profitabilitas mempunyai koefisien beta sebesar 0.077 . hasil ini berarti memiliki pengaruh positif signifikan terhadap peringkat obligasi. Nilai probabilitas variabel profitabilitas dalam penelitian ini adalah sebesar 0.0025 . nilai tersebut lebih kecil dari tigkat signifikansi (a) $=5 \%$ atau 0.05 , yang berarti profitabilitas berpengaruh langsung dan positif sigifikan terhadap peringkat obligasi. Hasil analisis ini menunjukkan bahwa $\mathrm{H}_{0}$ ditolak dan $\mathrm{h}_{a}$ diterima. Oleh karena itu, dapat disimpulkan bahwa profitabilitas mempunyai pengaruh langsung dan positif signifikan terhadap peringkat obligasi.

Hal ini senada dengan yang dikemukakan oleh Syawal dan Fachrizal (2016), Wahono (2018) dan Dewi dan Utami (2020) yang membuktikan bahwa profitabilias memiliki pengaruh terhadap peringkat obligasi. Semakin tinggi ROE, maka semakin tinggi peringkat obligasinya.

\section{Kesimpulan dan Saran}

\subsection{Kesimpulan}

Berdasarkan hasil penelitian yang dilakukan pada Bank Konvensional periode tahun 20152019 yang terdaftar di Bursa Efek Indonesia dan diperingkat oleh PT. PEFINDO, maka dapat disimpulkan sebagai berikut: (1) Leverage tidak berpengaruh signifikan terhadap peringkat obligasi, sehingga $\mathrm{H}_{1}$ ditolak, (2) Firm size berpengaruh positif dan tidak signifikan terhadap peringkat obligasi, sehingga $\mathrm{H}_{2}$ ditolak, (3) Leverage melalui profitabilitas tidak memiliki pengaruh tidak langsung terhadap peringkat obligasi, sehingga $\mathrm{H}_{3}$ ditolak, (4) Firm size melalui profitabilitas memiliki pengaruh tidak langsung terhadap peringkat obligasi, sehingga $\mathrm{H}_{4}$ diterima, (5) Profitabilitas berpegaruh langsung positif signifikan terhadap peringkat obligasi $\mathrm{H}_{5}$ diterima.

\subsection{Saran}

Berdasarkan kesimpulan dan keterbatasan yang ada, maka saran yang dapat diberikan diantaranya adalah : bagi pihak perusahaan untuk meningkatkan kepercayaan investor dalam menanamkan investasi obligasi perbankan, maka perbankan harus memastikan agar nilai DER selalu terjaga atau bahkan turun, pihak perbankan juga disarankan untuk meningkatkan profitabilitas perusahaannya. Bagi pihak investor hendaknya melakukan investasi pada perusahaan yang memiliki DER rendah dan profitabilitas tinggi, investor juga disarankan utuk berinvestasi pada obligasi dengan kategori investment grade, yang diberikan rating oleh PT. 
Pefindo maupun perusahaan-perusahaan pemeringkat lainnya yang kredibel. Peneliti selanjutnya disarankan untuk dapat menambahkan faktor-faktor akuntansi lainnya seperti likuiditas dan gross profit margin, atau faktor non akuntansi seperti sinking fund, reputasi auditor, risk, serta menggunakan perusahaan non keuangan yang terdaftar di Bursa Efek Indonesia dan menambah periode penelitian agar hasil lebih akurat.

\section{Referensi}

Brigham, Edward J, and Houston (2011) Essential of Financial Management. Masen : South Western, Congage Learning.

Dewi, Sarasi, Mayang., Utami, Minda, Eristy. (2020). The Influence Of profitability, and Liqidity to Bond Rating and the Impact on the Bond Yield. International Journal of Research in Business and Social Science. Vol. 4 Hal 215-219.

Fauziah, Yossy. (2014). Pengaruh Likuiditas, Leverage, dan Umur Obligasi Terhadap Prediksi Peringkat Obligasi. Jurnal Akuntansi Universitas Negri Padang, 291), h : 1-24.

Hery. 2015. Analisis Laporan Keuangan. Yogyakarta : CAPS.

Ibrahim, Hadiasman. (2018). Pengaruh Tingkat Suku Bunga, Peringkat Obligasi, Ukuran Perusahaan dan DER Terhadap Yield to Maturity Obligasi Korporasi di Bursa Efek Indonesia Periode Tahun 20042006.

Kasmir. (2017). Analisis Laporan Keuangan. Jakata : PT. Raja Grasindo

Kidwell, David S., Blackwell, David W., Whidbee, David A. (2016). Financial, Institutiona, Market and Money. Twelfth Edition. LCSH : Finance - United State.

Klasifikasi ukuran perusahaan menurut UU No. 20 Tahun 2008

Leli, Misarah. (2017). Transaksi Obligasi Syariah (Tinjauan Transaksi Obligasi Meurut Prinsip-Prinsip Syariah). Vol. 16 No. 1

Ghozali, Imam. (2013). Aplikasi Analisis Multivariate dengan Program IBM SPSS. Semarang: Badan Penerbit UNDIP.

Handyansyah, Muhamad Reza dan Lestari, P Dina. (2016). Pengaruh Return on Asset (ROA), Return On Equity (ROE), Net Profit Margin (NPM), dan Earning Per share (EPS), Terhadap Harga Saham Pada Perusahaan yang Terdaftar dalam Indeks LQ45 Bursa Efek Indonesia tahun 2012 - 2015. Ejournal : UNDIP [Online] diakses pada 20 Februari 2020.

Harahap , S. S. (2010). Analisis Kritis Atas Laporan Keuangan. Jakarta: PT. Raja Grafindo Persada.

Hartono, Jogianto. (2015). Teori Perfotofolio dan Analisis Investasi. Edisi Kesepuluh Yogyakarta: BPFE.

Hidayat, W.W. (2018). Pengaruh Leverage dan Likuiditas Terhadap Peringkat Obligasi : Studi Kasus Perusahaan Non Keuangan di Indonesia. Jurnal Riset manajemen dan Bisnis (JRMB) Fakultas Ekonomi UNIAT. No. 3 Vol. 3 Hal. 387-394 
Novtaviani, Rizna., Oetomo, Hening, Widi. (2019). Pengaruh Likuiditas, Profitabilitas, Intellectual Capital Terhadap Peringkat Obligasi Perbankan di BEl. Jurnal IImu dan Riset Manajemen. Vol. 8 No. 2

Phety, Debora, Tri, Oktarina. (2018). Pengaruh DER, CAR, dan ROE Terhadap Peringkat Obligasi Perbankan yang Listing di PT Bursa Efek Indonesia pada Periode 2008-2013. Jurnal Saintifik Manajemen dan Akuntansi. Vol. 01 No. 02.

Putri, Norisa., Mulyani, Erly. (2019). Pengaruh Rasio Hutang, Profit Margin dan Ukuran Perusahaan Terhadap Financial Distress (Studi Empiris Pada Perusahaan Sektor Utama Yang Terdaftar di Bursa efek Indonesia Tahun 2013-2017). Jurnal Eksplorasi Akuntansi. Vol. 1 No. 4 Hal 19668-1983

Rahardja, Prahatma., Manurung, Mandala. (2015). Pengantar Ilmu Ekonomi (Mikroekonomi dan Makroekonomi) Edisi ketiga. Jakarta : Lembaga Penerbit Fakultas Ekonomi Universitas Indonesia.

Sari, Ni Made Kristina., Badjra, Ida Bagus. (2016). Pengaruh Likuiditas, Ukuran Perusahaan, Leverage dan Jaminan Terhadap Peringkat Obligasi Pada Sektor Keuangan. Vol. 5 No. 8 Hal 5041-5069.

Sakinah, Putri., Parminto, Ardi., kadafi, M. Amin. (2017). Analisis Faktor Keuangan da Non Keuangan yang Mempengaruhi Prediksi Peringkat Obligasi (Studi Empiris Pada Perusahaan Penerbit Obligasi yang Terdaftar di Bursa Efek Indonesia Periode 2012-2014). Vol. 14 No. 1

Saputri, Desak, Putu, Opti, Sani., Purbawangsa, Ida, Bagus. (2016). Pengaruh Leverage, Profitabilitas, Pertumbuhan Perusahaan, dan Jaminan Terhadap Peringkat Obligasi Sektor Jasa di Bursa efek Indonesia. E-Jurnal Manajemen Unud. Vol. 5 No. 6 Hal 3706-3735

Sartono, Agus. (2012). Manajemen Keuangan Teori dan Aplikasi. Edisi Keempat. Yogyakarta : BPEE

Syawal, Teuku Muhamad., Fachrizal. (2016). Pengaruh Profitabilitas, Interest Coverage Ratio, Retained Earning, dan Pertumbuhan Perusahaan Terhadap Peringkat Obligasi Pada perusahaan Non Keuangan Yang Terdaftar di Bursa Efek Indonesia Tahun 2012-2014. Jural Ilmiah Mahasiswa Ekonomi Akuntansi. Vol. 1 No. 2 Hal. 237-251.

Veronica. Aries. (2015). Faktor-Faktor Yang Mempengaruhi Peringkat Obligasi Pada Perusahaan Manufaktur. ( 2015). Vol. 13 No. 2 Hal $272-282$.

Wahono, Dwi Tyas Cahyo., Sadikin, Ali., Widyarfendhi. (2018). Pengaruh Rasio Keuangan Terhadap Peringkat Obligasi Perusahaan Manufajtur yang Terdaftar di Bursa Efek Indonesia Tahun 20102011. Jurnal Spread. Vol. 8 No. 1.

Wijayanti, Indah., Priyadi, Maswar, Patuh. (2015). Faktor-Faktor yang Mempengaruhi Peringkat Obligasi. Jurnal Ilmu dan Riset Akuntansi. Vol 3 No. 3

Wijayanti, Puput. (2011). Pengaruh Intellectual Capital Terdadap Harga Saham melalui Kinerja Keuangan Pada perusahaan Perbankan Yang Terdaftar di Bursa Efek Indonesia (BEI) Tahun 2009-2011. Malang : Universitas Brawijaya. 